\title{
EVIDENCE OF TERRESTRIAL FEEDING IN THE ARBOREAL LIZARD Enyalius bilineatus (SAURIA, POLYCHROTIDAE) OF SOUTH-EASTERN BRAZIL
}

\author{
ZAMPROGNO, C., ${ }^{1}$ ZAMPROGNO, M. das G. F. ${ }^{1}$ and TEIXEIRA, R. L. ${ }^{2}$ \\ ${ }^{1}$ Departamento de Biologia, Universidade Federal do Espírito Santo, CEP 29040-090, Vitória, ES, Brazil \\ ${ }^{2}$ Museu de Biologia Prof. Mello Leitão, Av. José Ruschi, 4, CEP 29650-000, Santa Teresa, ES, Brazil \\ Correspondence to: Rogério L. Teixeira, Museu de Biologia Prof. Mello Leitão, Av. José Ruschi, 4, Centro, \\ CEP 29650-000, Santa Teresa, ES, Brazil, e-mail: teixeira@sigma.tropical.com.br \\ Received August 26, 1999 - Accepted February 15, 2000 - Distributed February 28, 2001
}

(With 1 figure)

\begin{abstract}
The diet of the arboreal lizard E. bilineatus was assessed based on analysis of gut contents of specimens collected in the remnants of the Atlantic rainforest in Espírito Santo State, south-eastern Brazil. Stomachs of the lizards examined $(\mathrm{SVL}=57.0-85.0 \mathrm{~mm})$ contained nine arthropod orders. E. bilineatus utilizes a broad range of arthopodan prey type and sizes, and can be considered an arthropod generalist, which uses a sit-and-wait foraging strategy. Orthoptera represented the most important food item, followed by Dictyoptera and Hymenoptera. Hemiptera, Homoptera, Lepidoptera (larvae), Coleoptera, Araneae, and Diplopoda constituted the remainder of food items. The presence of Diplopoda, which are not generally found on tree trunks, provides particularly strong evidence the E. bilineatus forages in leaf litter on the ground.
\end{abstract}

Key words: Enyalius, Polychrotidae, food habits, Atlantic Forest, south-eastern Brazil.

\section{RESUMO}

Evidência do hábito alimentar terrestre no lagarto arborícola Enyalius bilineatus (Sauria, Polychrotidae) do sudeste do Brasil

A dieta do lagarto arborícola E. bilineatus foi avaliada com base na análise de conteúdo estomacal de espécimens coletados em áreas remanescentes da floresta Atlântica do Estado do Espírito Santo, sudeste do Brasil. Nos estômagos dos lagartos examinados (CRA = 57,0-85,0 mm; mean $=72,9 \mathrm{~mm}$ ) foram obtidas nove ordens de artrópodes. E. bilineatus utiliza uma ampla variedade de artrópodes em sua dieta, podendo ser considerado como artrópode generalista, o qual utiliza a tática de forrageamento do tipo senta-e-espera. Orthoptera representou o mais importante item alimentar, seguido por Dictyoptera e Hymenoptera. Hemiptera, Homoptera, larva de Lepidoptera, Coleoptera, Araneae e Diplopoda constituíram os demais itens alimentares. A presença de Diplopoda, que geralmente não ocorre em árvores, sugere que E. bilineatus forrageia principalmente no solo.

Palavras-chave: Enyalius, Polychrotidae, hábito alimentar, Floresta Atlântica, sudeste do Brasil.

\section{INTRODUCTION}

The arboreal lizard Enyalius bilineatus is a poorly-known polychrotid lizard of the Atlantic rain forest of south-eastern Brazil. Very little information is available concerning the ecology and natural history of this species. It has been asserted that members of the genus Enyalius are arboreal (Etheridge, 1969). However, Vanzolini (1972) presented evidence from analysis of gut contents of 42 specimens that $E$. catenatus spents much time foraging on the ground, and Sazima \& Haddad 
(1992) observed E. iheringii both in leaf litter and on the trunks.

Vanzolini (1972) also reported gut contents of two specimens of $E$. bilineatus but drew no conclusions from this small sample. To our knowledge, Vanzolini's (1972) report is the only published ecological information for E. bilineatus.

Here, we report on the diet of E. bilineatus, based on analysis of gut contents of specimens collected in the remnants of the Atlantic rainforest in Espírito Santo State, south-eastern Brazil.

\section{MATERIAL AND METHODS}

Lizards were caught by plantation workers in the remnants of hilly Atlantic rainforest near Sítio Três Marias, municipality of Marechal Floriano, State of Espírito Santo, South-eastern Brazil (ca. 20²4'S, 4049' W; 600-700 m elevation), from February 1995 to March 1996. In this area, the climate is seasonal with well defined dry/cold (June-September) and rainy-warm (October-March) seasons (Féboli, 1993). All lizards were killed upon capture, fixed in $10 \%$ formalin, and preserved in $70 \%$ alcohol. Snout-vent length (SVL mm) and body mass $(0.1 \mathrm{~g}$ precision) were recorded from preserved specimens.

Stomach contents were removed and prey items were identified to order and counted. Diet composition is described in terms of total numbers of food items and total number of stomachs containing particular food types. Length and width of intact and nearly intact prey items were measured with calipers. Incomplete (partly digested) prey was excluded from analysis of prey size. Voucher specimens are deposited in the zoological section of the Museu de Biologia Prof. Mello Leitão (MBML), located in the municipality of Santa Teresa, ES, and Museu de Zoologia da Universidade de São Paulo, south-eastern Brazil.

\section{RESULTS AND DISCUSSION}

Stomachs of 48 lizards were examined $(\mathrm{SVL}=57.0-85.0 \mathrm{~mm}$; mean $=72.9 \mathrm{~mm})$, and 45 contained food items. Nine arthropod orders were identified in the gut contents of E. bilineatus (Table 1). Orthoptera represented the most important food item in terms of both, total numbers of items and the number of stomachs, followed by Dictyoptera and Hymenoptera. Hemiptera, Homoptera, Lepidoptera (larvae), Coleoptera, Araneae, and Diplopoda constituted the remainder of food items.

Vanzolini (1972) reported Homoptera in one and Hymenoptera, Dyctioptera, Orthoptera and lizard skin in the other of his two specimens of E. bilineatus. The lizard skin was presumably the lizard's own.

TABLE 1

Occurrence and numerical frequencies of prey found in the stomachs of Enyalius bilineatus of south-eastern Brazil.

\begin{tabular}{|l|c|c|}
\hline \multicolumn{1}{|c|}{ Prey } & \% Occurrence & \% Number of prey \\
\hline Orthoptera & 46.7 & 12.8 \\
\hline Dyctioptera & 24.4 & 17.0 \\
\hline Hymenoptera & 22.2 & 6.4 \\
\hline Coleoptera & 20.0 & 8.5 \\
\hline Hemiptera & 13.3 & 1.1 \\
\hline Lepidoptera (larvae) & 17.8 & - \\
\hline Homoptera & 2.2 & 7,4 \\
\hline Insect remains & 2.2 & 9.6 \\
\hline Diplopoda & 8,9 & - \\
\hline Araneae & 15.6 & - \\
\hline Piece of leaves & 2.2 & - \\
\hline Total of lizards & 48 & 94 \\
\hline Full stomachs & 45 & - \\
\hline Total number of prey & - & \\
\hline
\end{tabular}


The length of prey $(\mathrm{N}=42)$ ranged from 2.1 to $28.2 \mathrm{~mm}$ (mean $=9.1$ ) and the width ranged from 1.1 to $5.3 \mathrm{~mm}($ mean $=2.4)$. Correlation between the length and width of prey, and snout-vent length (SVL) of E. bilineatus was not significant (Pearson correlation test; $\mathrm{p}>0.05$ ).

The analysis of gut contents shows that $E$. bilineatus utilizes a broad range of arthopodan prey type and sizes, and can be considered an arthropod generalist. The diet of the lizards can be related to the type of microhabitat, activity time, and foraging strategy (Vrcibradic \& Rocha, 1996), and a generalist diet may be related to a sit-and-wait foraging strategy (sensu Pianka, 1973), which is the strategy of polychrotid lizards (Vitt \& Durtsche, 1995; Vitt \& Zani, 1996). The observations of Sazima \& Haddad (1992) on E. iheringii are consistent with its use of a sit-and-wait strategy.

Polychrotid lizards are considered a primarily arboreal group, although some species are terrestrial (see Vitt \& Lacher, 1981; Duellman, 1987; Martins, 1991; Vitt \& Durtsche, 1995). Most of the prey items found in E. bilineatus are considered common inhabitants of leaf litter in neotropical rainforests, and constitute important food resources for small, terrestrial anurans and lizards (Vitt \& Caldwell, 1994). Similar items in the diet of E. catenatus (Dyctioptera, Coleoptera larvae, Orthoptera, Diplopoda, Chilopoda, Phalangida and Oligochaeta) led Vanzolini (1972) to conclude that this species engaged in terrestrial foraging. Some of the items found in E. bilineatus could equally have been obtained through terrestrial or arboreal foraging, but the presence of Diplopoda, which are not generally found on tree trunks, provides particularly strong evidence the E. bilineatus forages in leaf litter on the ground. In addition, two stomachs contained dry leaf fragments, probably ingested along with arthropod prey on the forest floor.

We observed E. bilineatus in both, on the trunks and on the ground within the study area, but did not observe feeding. The forest floor consist of a layer of leaf litter over decayed humus on clay.

The color of E. bilineatus (wide, dark brown, cream edged bands along the side of neck and body) is disruptive and closely matches the dead leaves of the forest floor, providing excellent camouflage (Fig. 1). Its stationary sit-and-waiting foraging strategy may also protect this lizard against visually oriented predators.

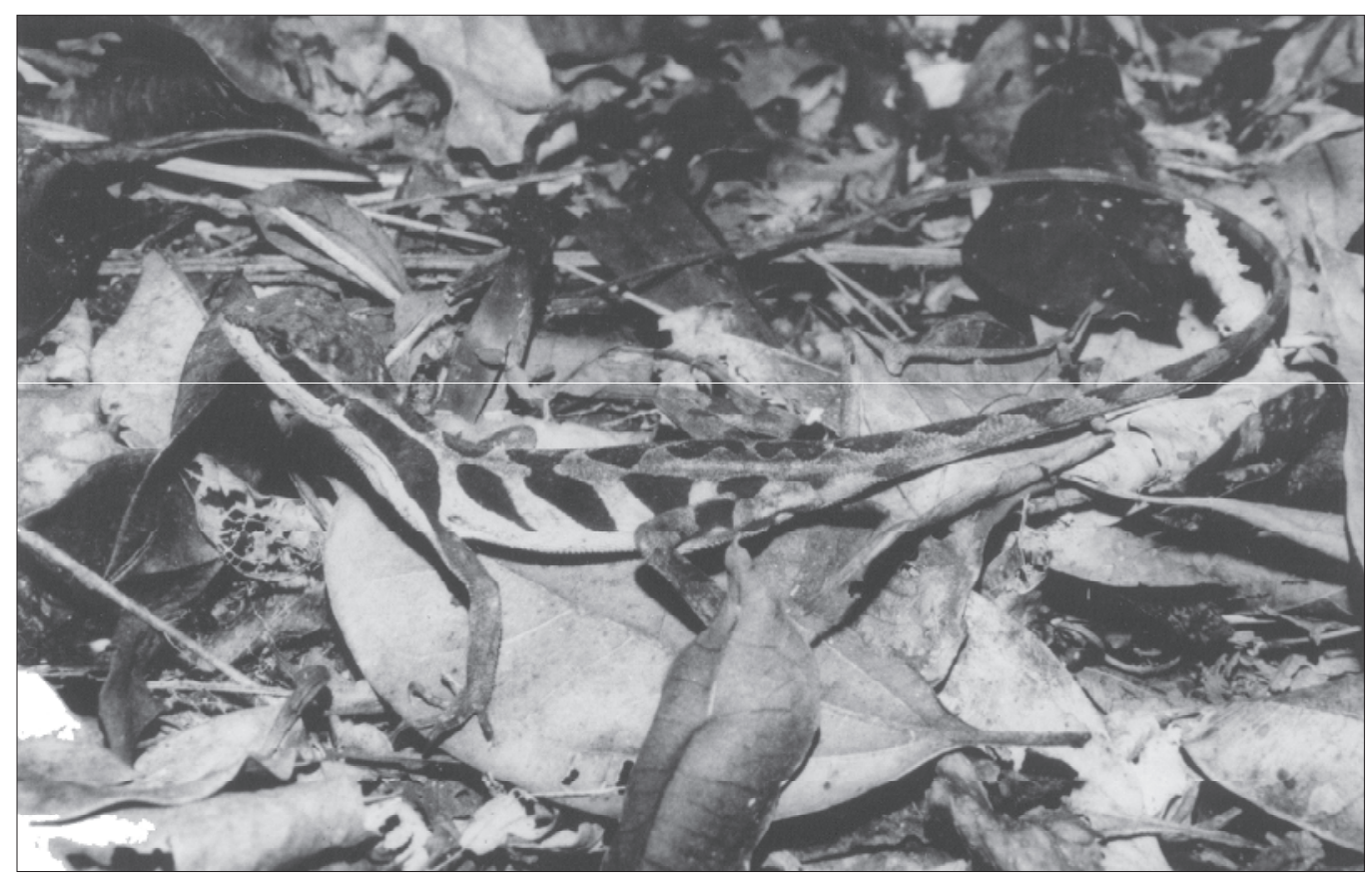

Fig. 1 - Adult male Enyalius bilineatus showing its cryptic coloration against a typical background of forest floor. 
The limited data indicate that species of Enyalius exploit both terrestrial (leaf litter) and arboreal habitats and are not strictly arboreal. Indeed, while these data indicate that Enyalius species feed in leaf litter there is no clear evidence of feeding in arboreal habitats. It is possible that Enyalius species feed in both terrestrial and arboreal habitats, and that the diversity of feeding opportunities the two habitats provide partly explains their use of both habitats. Alternatively, arboreal habitats may be used primarily as refuges for avoiding predators. It is clear that Enyalius sleeps on the trees (Laurie E. Vitt, pers. comm.).

More data are needed to distinguish between these alternatives. If polychrotid lizards are ancestrally arboreal, then there would appear to have been a shift in habitat use in the evolution of Enyalius. However, too little is known about the natural history, ecology, and phylogenetic relationships of polychrotid lizards other than anolines, to allow firm conclusions on the direction of the shift in habitat use or its specifity to Enyalius.

Acknowledgments - We thank Laurie E. Vitt for critically reading the manuscript, and Miguel T. Rodrigues for confirmation of the identity of E. bilineatus. Financial support was provided by the PICD/CAPES (graduate fellowship for CZ), and CNPq (grant to RLT, Proc. N. 302657/87-8) and 469321/ 2000-8.

\section{REFERENCES}

DUELLMAN, W. E., 1987, Lizards in an Amazonian rain forest community: resource utilization and abundance. Natl. Geogr. Res., 3(4): 489-500.

ETHERIDGE, R., 1969, A review of the iguanid lizard genus Enyalius. Bull. British Mus. (Nat. Hist.) Zool., 19(8): 233-260.
FÉBOLI, W. L., 1993, Programa levantamentos geológicos básicos do Brasil. Domingos Martins. Folha SF. 24-VA-III. Estado do Espírito Santo. Escala 1:1000.000, DNPM/CPRM, 179p.

MARTINS, M., 1991, The lizards of Balbina, Central Amazonia, Brazil: A qualitative analysis of resource utilization. Studies on Neotropical Fauna and Environment, 26(3): 179-190.

PIANKA, E. R., 1973, The structure of lizard communities. Annual Review of Ecology and Systematics, 4: 53-74.

SAZIMA, I. \& HADDAD, C. F. B., 1992, Répteis da Serra do Japi: notas sobre história natural. In: L. P. C. Morellato (org.), História Natural da Serra do Japi: Ecologia e Preservação de uma Área Florestal no Sudeste do Brasil. Editora da Unicamp, Campinas.

VANZOLINI, P. E., 1972, Miscellaneous notes on the ecology of some Brazilian lizards (Sauria). Papéis Avulsos Zool., São Paulo, 26(8): 83-115.

VITT, L. J. \& CALDWELL, J. P., 1994, Resource utilization and structure of small vertebrates in the Amazon forest leaf litter. Journal of Zoology, London, 234: 463476.

VITT, L. J. \& LACHER, T. E., Jr., 1981, Behavior, habitat, diet, and reproduction of the iguanid lizard Polychrus acutirostris in the Caatinga of northeastern Brazil. Herpetologica, 37(1): 53-63.

VITT, L. J. \& ZANI, P. A., 1996, Ecology of the South American lizard Norops chrysolepis (Polychrotidae). Copeia, 1996(1): 56-68.

VITT, L. J. \& DURTSCHE, R. D., 1995, Ecology of the lizard Norops oxylophus (Polychrotidae) in lowland forest of south-eastern Nicaragua. Canadian Journal of Zoology, 73: 1918-1927.

VRCIBRADIC, D. \& ROCHA, C. F. D., 1996, Ecological differences in tropical sympatric skinks (Mabuya macrorhyncha and Mabuya agilis) in southeastern Brazil. J. Herpetol., 30(1): 60-67. 